\title{
DEVELOPMENT OF THE LEASING INDUSTRY IN THE ALBANIAN MARKET. AN OVERVIEW OF THE LAST 20 YEARS FROM LEGAL FRAMEWORK TO PERFORMANCE INDICATORS

\author{
Fatjola Lubonja ${ }^{1}$
}

\begin{abstract}
Financial leasing, known as well as the financial rent, has been available in the Albanian market since 2005 although most of the leasing operating companies have only been registered since 2009. Even though in developing countries financial leasing is widely available and growing considerably, in the case of Albania this product has faced difficulties in getting recognition in the eyes of the public. Based on the European practices, small and middle enterprises compose $99 \%$ of the operating businesses in Albania and these types of enterprises are among the main users of leasing in Europe, about 50\%. These elements are exactly what made leasing an alternative to financial borrowing even though financial leasing yet has an unused potential compared to loans and other forms of financing. This article aims to give a general description of the meaning of financial leasing, the legal and the regulatory framework in which this form of financing has been applied in Albania and further provide several conclusions that will focus on the factors that are expected to affect the future of financial leasing in Albania.

JEL Classification Numbers: G30, G31; DOI: http://dx.doi.org/10.12955/cbup.v6.1177
\end{abstract}

Keywords: leasing, portfolio, assets, financial leasing

Introduction. What does one understand about financial leasing and what are its development dynamics in Albania?

Definitions of leasing differ considerably in different jurisdictions for tax, legal, and accounting purposes. Leasing has been variously defined in literature. In its simplest form is a means of delivering finance, broadly defined as "a contract between two parties where one party (the lessor) provides an asset for usage to another party (the lessee) for a specified period of time, in return for specified payments." Leasing, in effect, separates the legal ownership of an asset from the economic use of that asset (IFC, 2009). In Albanian legislation, the financial leasing was first mentioned in the "Civil Code of the Republic of Albania", specifically in Article 849 "Financial rent/leasing (Leasing)". It states that through financial rent/leasing one of the parties is legally bound to make available a movable or immovable object, based on a periodic limited payment, defined in accordance to the value of the object, within the duration of the contract. The object can also be built by the lessor according to the demands of the lessee, which has the right to gain ownership at the end of the contract duration.

The leasing program was established in October 2003 as cooperation between the Albanian Ministry of Economy and the Economic Cooperation of Southern Europe. The law on "financial rent" was approved by the Albanian Parliament in May 2005. This law regulates the relations of the financial rent, i.e. the type of relationship which is provided by the financial rent/leasing of movable and immovable object and it has some distinctive peculiarities from other forms of rents such as: a- the active object to this agreement is selected by the lessee on its own in full independence from the lessor. b- the selected object by the lessee, is bought or occasionally built with the financial equipment of the lessor, with the only purpose to provide it for financial rent, according to the contract bound or that the parties will bind and to which the supplier has full acknowledgement. c- the rent is a form of payments which is calculated considering the amortization of the object $d$ - at the end of the financial rent/leasing contract, the lessee has the right: to buy the object by paying a symbolic payment predefined by the parties in the binding contract or defined in the moment of exercising the right of buying, to renew the contract for another duration of time according to a rent payment lower than the initial one, or to return the object to the lessor. The law defines the parties which may be part of this type of relationship. According to the law the right to be subject of this relationship as a lessor is denied to all the financial institutions and banks if this is not defined explicitly in the respective license. The lessor must be a legal person with a founding capital of 20.000.000ALL and cannot exercise any other activity besides that of financial rent. A lessee can be any natural or legal person, native or foreign and does not have to necessarily live or exercise activity in the territory of the Republic of Albania.

\section{Development of financial leasing in Albania over the years}

The first mention of financial leasing in the Albanian legislation was in the "Civil Code of the Republic of Albania", namely in Article 849 "Financial Leasing". There it states that based on a lease agreement,

\footnotetext{
${ }^{1}$ Agricultural University of Tirana, Faculty of Economic and Agriculture, Department of Finance-Accounting, fatjola.lubonja@gmail.com
} 
one party shall be bound to make available to the other party, for a certain period of time, a movable or immovable property, against a payment on recurrent periods, set out in connection with the worth of the property item, contract duration and eventually with other elements referring to the agreement of the parties. In addition, the property item shall be acquired or constructed by the lessor in response to the wish of the lessee and the latter shall, upon the expiry of the contract duration, be entitled to acquire ownership over it, against the payment of predetermined amount.

From 2001, the Bank of Albania has licensed 13 non-banking financial entities to conduct the activity of financial leasing (as a sole activity or along with other activities). The first entity to have been granted the license for carrying out the activity of financial leasing is "Credins Leasing".

Among the main factors influencing the increase in the demand for financial leasing licenses was the change of the law Nr. 9396 "On financial leasing" and the reaction of banking groups to the effects of the international financial crisis of 2008. Year 2009 can be called the "financial leasing year" in terms of licensed entities. This can be seen in the fact that out of five entities licensed in 2009 , three belong to foreign banking groups. In addition, after 2008 the performance of financial leasing assets increased (in absolute terms) and peaked in 2012, whereas in relative terms it is difficult to make comparisons due to the low initial level. The increase in financial leasing assets has coincided with an increase in the number of licensed entities.

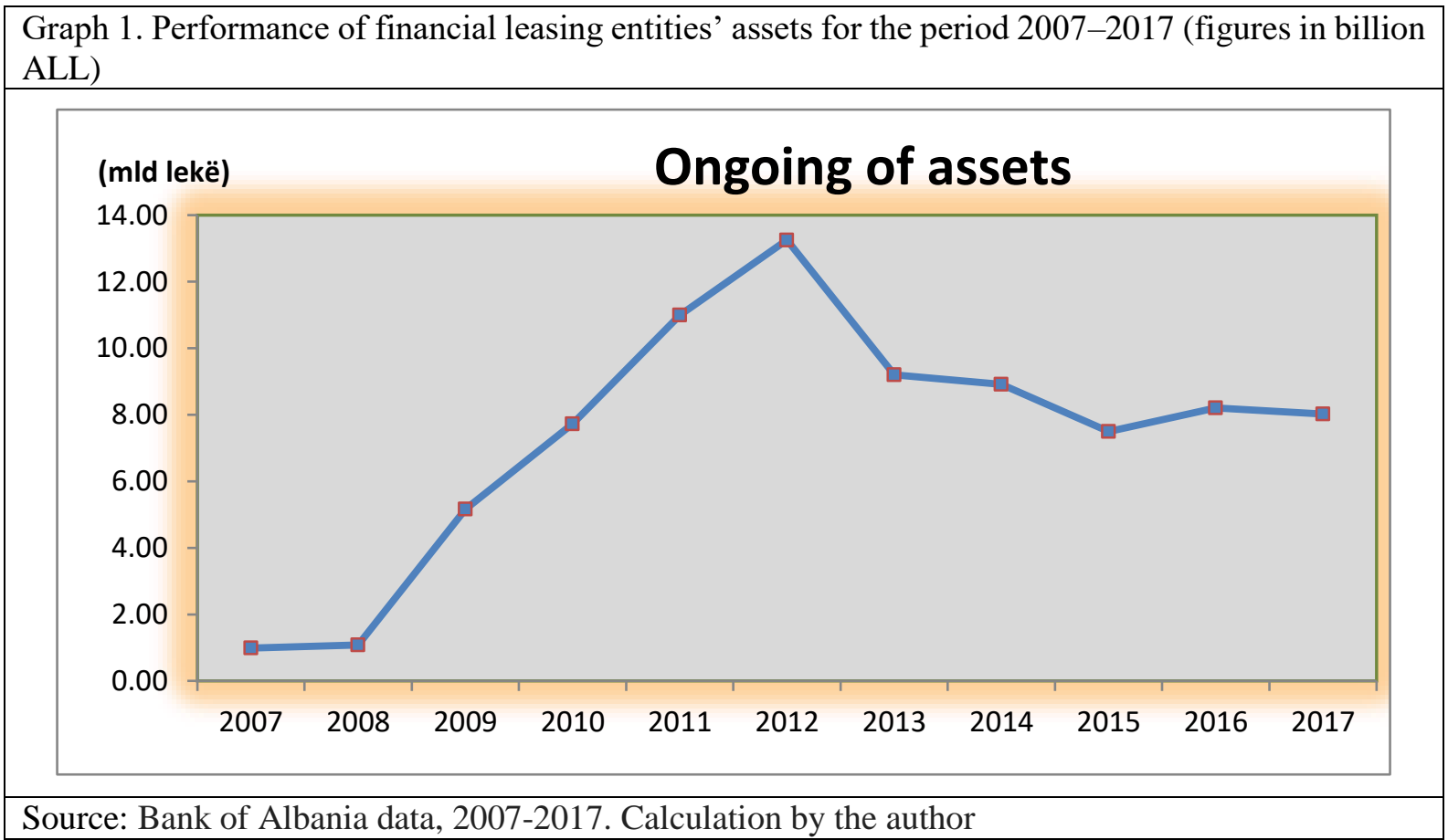

From 2013, there has been a merging of some of the key financial leasing entities, which were part of banking groups operating in Albania. The main reasons for this relate to the entity shareholders' assessments of the effectiveness of operational cost management, capital and other resources, as well as strategic plans for their presence in Albania. These processes resulted in the absorption of financial leasing entities by the banks of the group they were part of (Credins Leasing and Sogelease), or the sale of their portfolio to other entities (Tirana Leasing).

The most noticeable (negative) effects on the reduction of the use of financial leasing appeared in 2013 (when Credins Leasing was absorbed by Credins bank), whereas the sale of Tirana Leasing's portfolio to another entity (Raiffeisen Leasing), only had a minimal impact on the market.

Meanwhile, from 2015 onwards a stagnation of financial leasing activity can be observed, which to some extent reflects the slowdown in market demand for credit.

\footnotetext{
${ }^{2}$ Until 2012 there was no division between the volume of financial leasing activities and other activities.
} 
However, the interest of entities to be licensed as financial institutions has not decreased. During 20132017, 6 new non-banking entities were licensed to perform some of the leasing activities provided by law (lending, factoring, etc.), including financial leasing.

The only entity licensed for financial leasing activity, which has never exercised it, is the "Tranzit" entity (because this entity performs other activities).

\begin{tabular}{|c|c|c|c|c|c|}
\hline No. & Financial Leasing Entities & $\begin{array}{l}\text { License } \\
\text { date }\end{array}$ & $\begin{array}{l}\text { License } \\
\text { revocation }\end{array}$ & $\begin{array}{c}\text { Part of } \\
\text { banking } \\
\text { group }\end{array}$ & $\begin{array}{c}\text { Share of } \\
\text { financial } \\
\text { lease } \\
\text { (September } \\
\text { 2017) }\end{array}$ \\
\hline 1 & Credins Leasing & 13.06.2001 & 22.04.2016 & YES & $\mathrm{n} / \mathrm{a}$ \\
\hline 2 & Raiffeisen Leasing & 15.07.2009 & - & YES & $100 \%$ \\
\hline 3 & $\mathrm{FIN}-\mathrm{AL}$ & 20.02 .2009 & - & NO & $80 \%$ \\
\hline 4 & Tirana Leasing & 11.12.2009 & 30.11 .2016 & YES & $\mathrm{n} / \mathrm{a}$ \\
\hline 5 & Landeslease & 24.12.2009 & - & YES & $100 \%$ \\
\hline 6 & Sogelease & 25.01 .2010 & 30.05 .2013 & YES & $\mathrm{n} / \mathrm{a}$ \\
\hline 7 & Tranzit & 04.08 .2010 & & YES & $0 \%$ \\
\hline 8 & Tirana Factoring \& Lease & 28.03 .2013 & - & NO & $21 \%$ \\
\hline 9 & Porshe Leasing & 29.10 .2013 & & YES & $100 \%$ \\
\hline 10 & Albania Leasing & 21.04 .2014 & - & YES & $100 \%$ \\
\hline 11 & Crimson Finance Fund Albania (CFFA) & 02.10 .2015 & & NO & $52 \%$ \\
\hline 12 & Albanian Financial Institution & 30.05 .2016 & & NO & $99.6 \%$ \\
\hline 13 & MOGO Albania & 10.11.2017 & - & NO & $\mathrm{n} / \mathrm{a}$ \\
\hline
\end{tabular}

\section{Regulatory framework}

At the beginning of 2013, the Bank of Albania approved new regulation "On supervising the risk in the activity of non-bank financial institutions", and introduced new reporting requirements, which provide more detailed information, among other things, for financial leasing activities.

This regulation has set the classification of the financial leasing portfolio, as well as the relevant rates for its provision, which did not exist in the previous regulatory framework.

With the changes made to the above regulation in 2017,are the factors influencing financial leasing activity, the increase of the allowed limit for open foreign exchange positions, the recognition of exchange rate risk mitigating instruments, the increase of elements recognized as part of capital, etc.

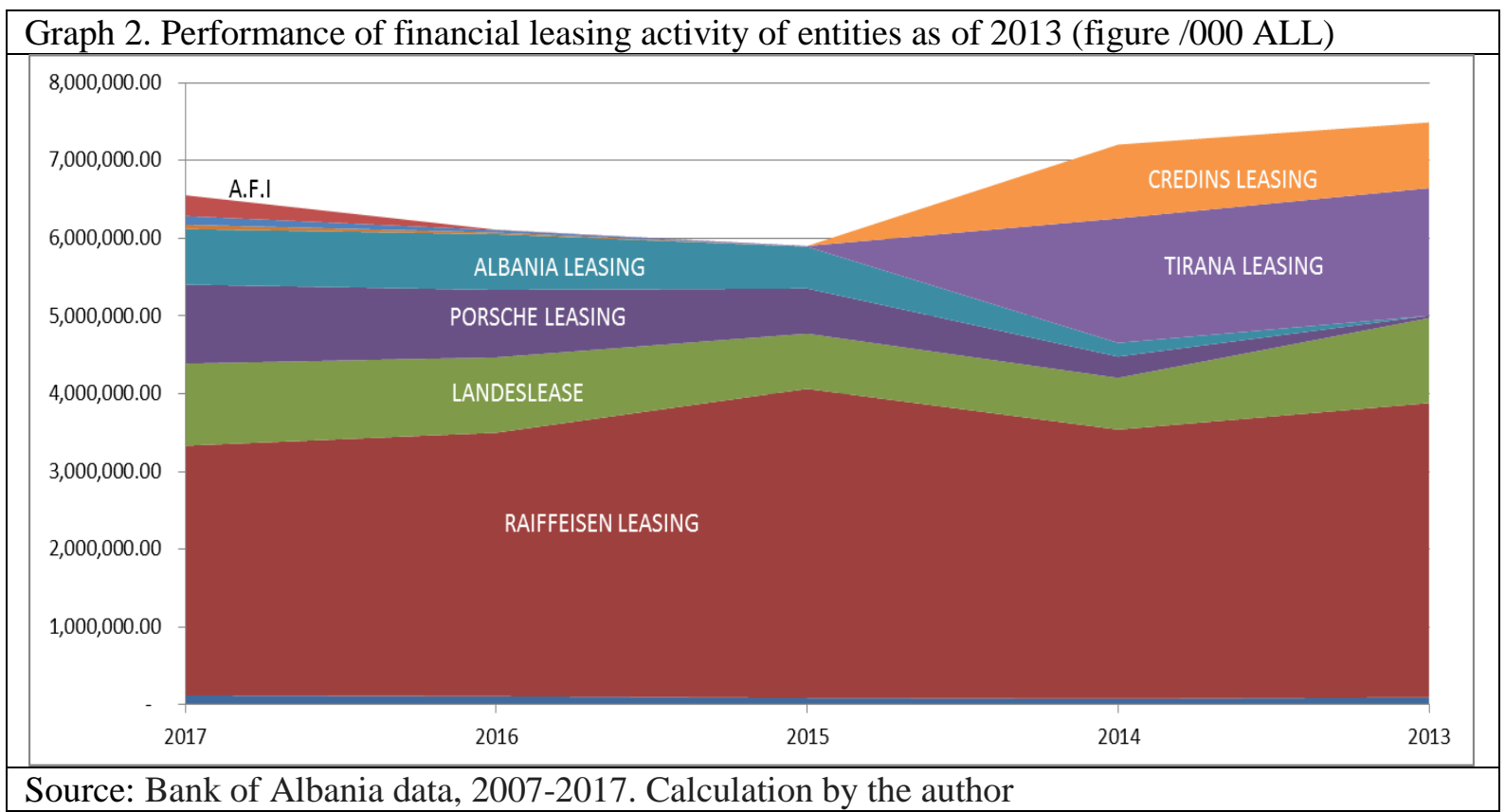




\section{Financial leasing portfolio over the years and its financing}

In September 2017, the gross financial leasing portfolio for non-banking financial institutions reached 6.55 billion ALL (about EUR 50 million). The entity that has dominated the market for years is "Raiffeisen Leasing" (49\%), with a significant gap in market share from other entities (Landeslease $16 \%$ and Porsche Leasing $-15.5 \%$ ).

Due to the quality of information before and after 2013 (explained above in the Regulatory Framework), the comparative information on the performance of the financial leasing activity is divided into two periods: 2007-2012 and 2013-September 2017.

For the first part of 2007-2012, the picture shows a slight shift in market dominance, but from 2011 and onwards, Raiffeisen Leasing is clearly is more dominant in the market than the other entities.
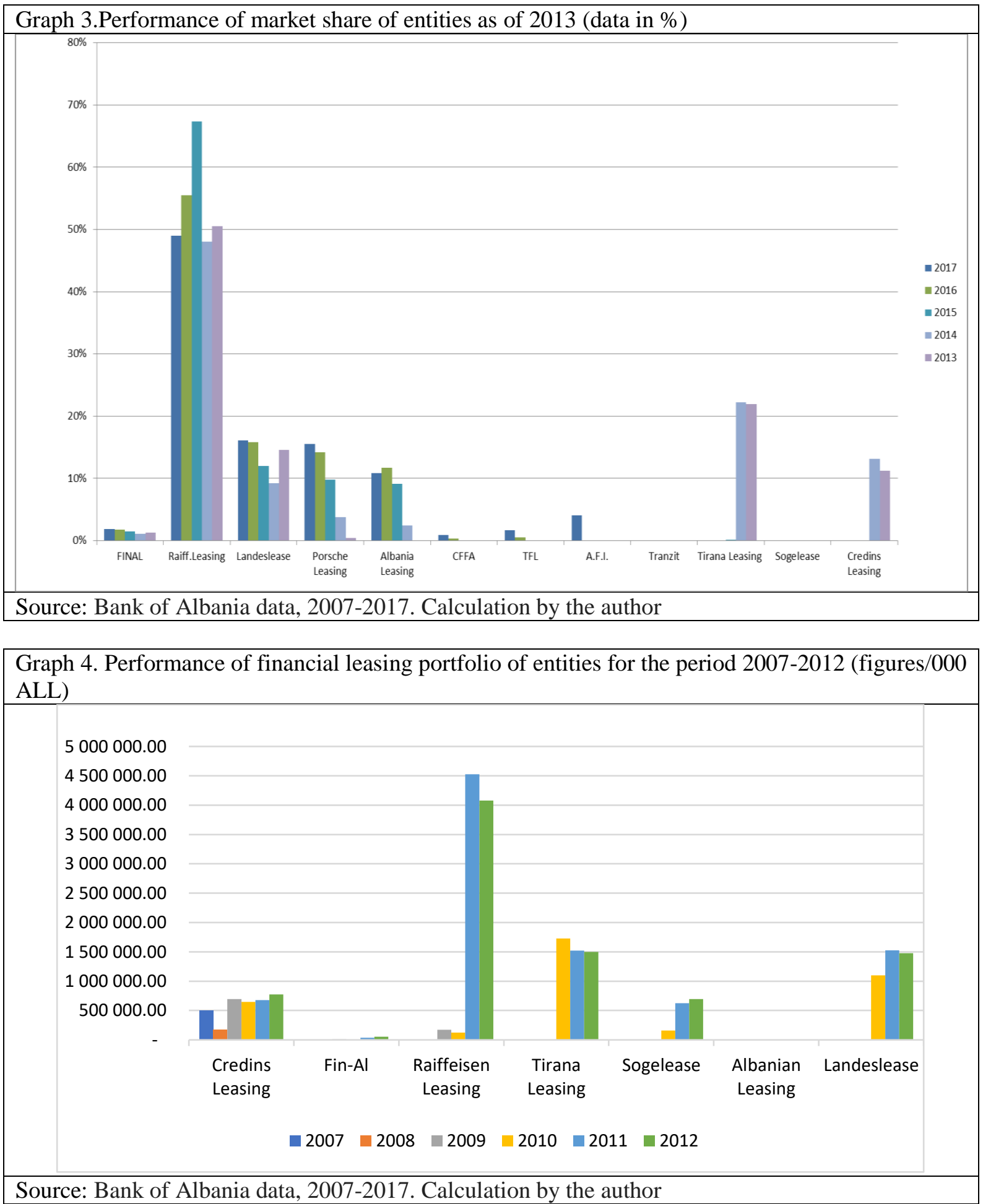
Raiffeisen Leasing's positioning is influenced by the strategy ${ }^{3}$ of the banking group it is a part of. This strategy has provided abundant financing resources for the entity, as well as a willing customer market, transferred by Raiffeisen Bank (the bank itself does not provide the financial leasing product or other loan products for the financing of personal or work goods, aimed at channeling customers to the financial leasing entity).

On the other hand, this strategy has also affected the non-performing financing indicator, which has followed almost the same performance as that of Raiffeisen Bank's non-performing loan portfolio. The main reasons relate to the financing of big bank customers, mainly for working machineries and production lines, as well as the fact that the deterioration of client's quality at the bank is also reflected in the financial leasing entity, as the analyses are carried out in a consolidated manner.

The other important entities in the financial leasing market are also bank-related entities, with some having a presence in both Albania and abroad, such as Porsche Leasing. The main advantage of such entities lies in the fact that they are highly financed by loans from group banks, thus increasing their leverage. The data reported during the analyzed period showed that credit financing fluctuates within the limits of 50-90\% of the liabilities for bank-related entities and 0-75\% for entities that are not related to banks.

It has to be underlined that financing of real estate, although still a smaller share in the financial leasing portfolio, has had a significant increase in the last two years, especially by new entities. Currently, this product is financed only by two entities (Albania Leasing and A.F.I.) and in the following year it is expected to be provided by another entity (Landeslease). As it turns out from the analysis of financing by sectors (see below), real estate financing is the sector with the second highest share of the financial leasing portfolio.

With regard to the age of financed products, new products remain dominant (60-70\%) compared to used products. This structure reflects the careful attitude of the entities to the value of the financed asset (collateral, mostly movable), which is reduced (depreciated) within a relatively short time.

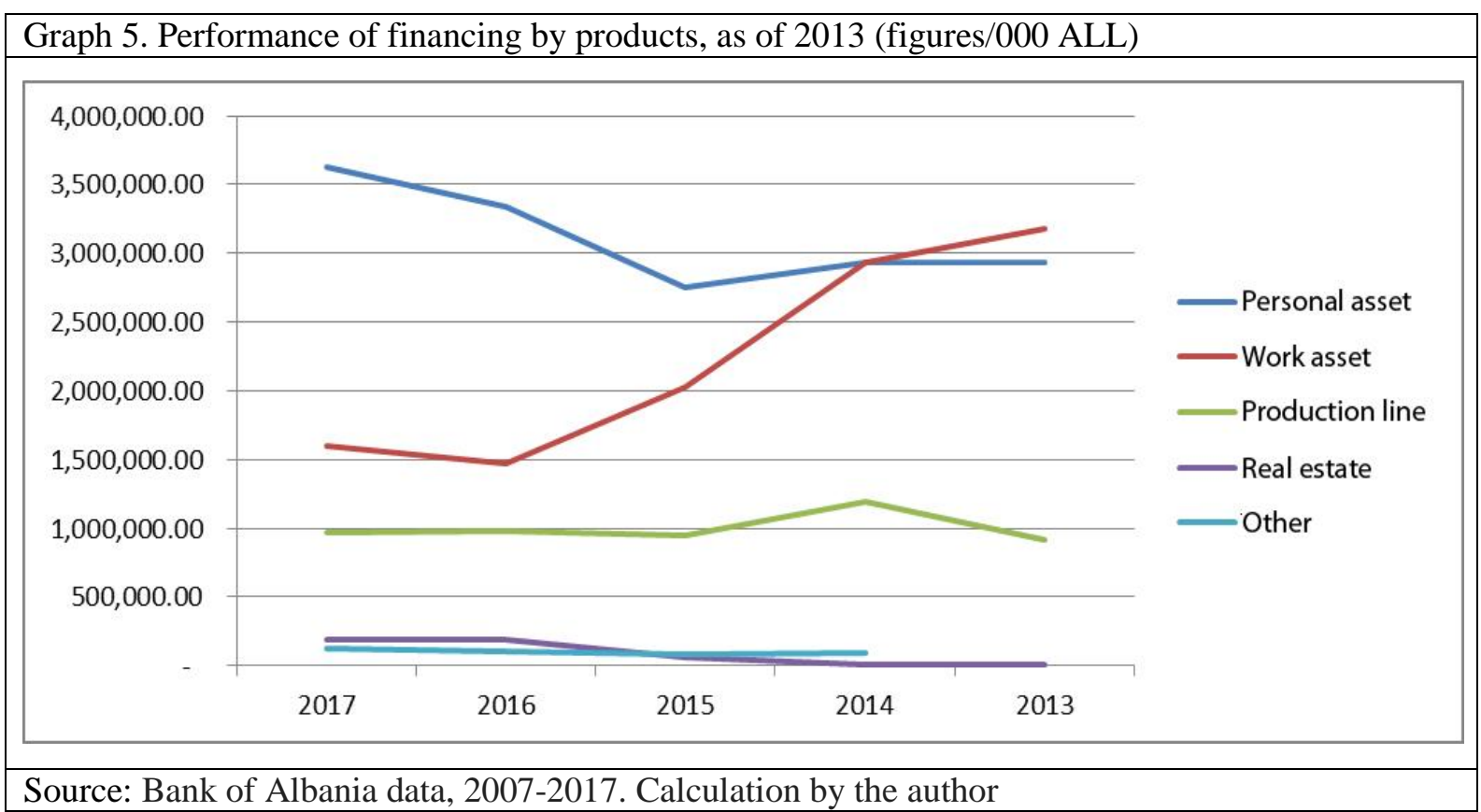

\footnotetext{
${ }^{3}$ RBI Banking Group, since 2011, has been under pressure from European supervisory authorities to reduce risk assets, including banking activity in Albania. For this reason, the group has decided that part of its activity is channeled into the financial leasing entity, to save short-term capital, and in the long run if necessary, be able to sell this entity to secure capital without affecting the bank's normal activity.
} 


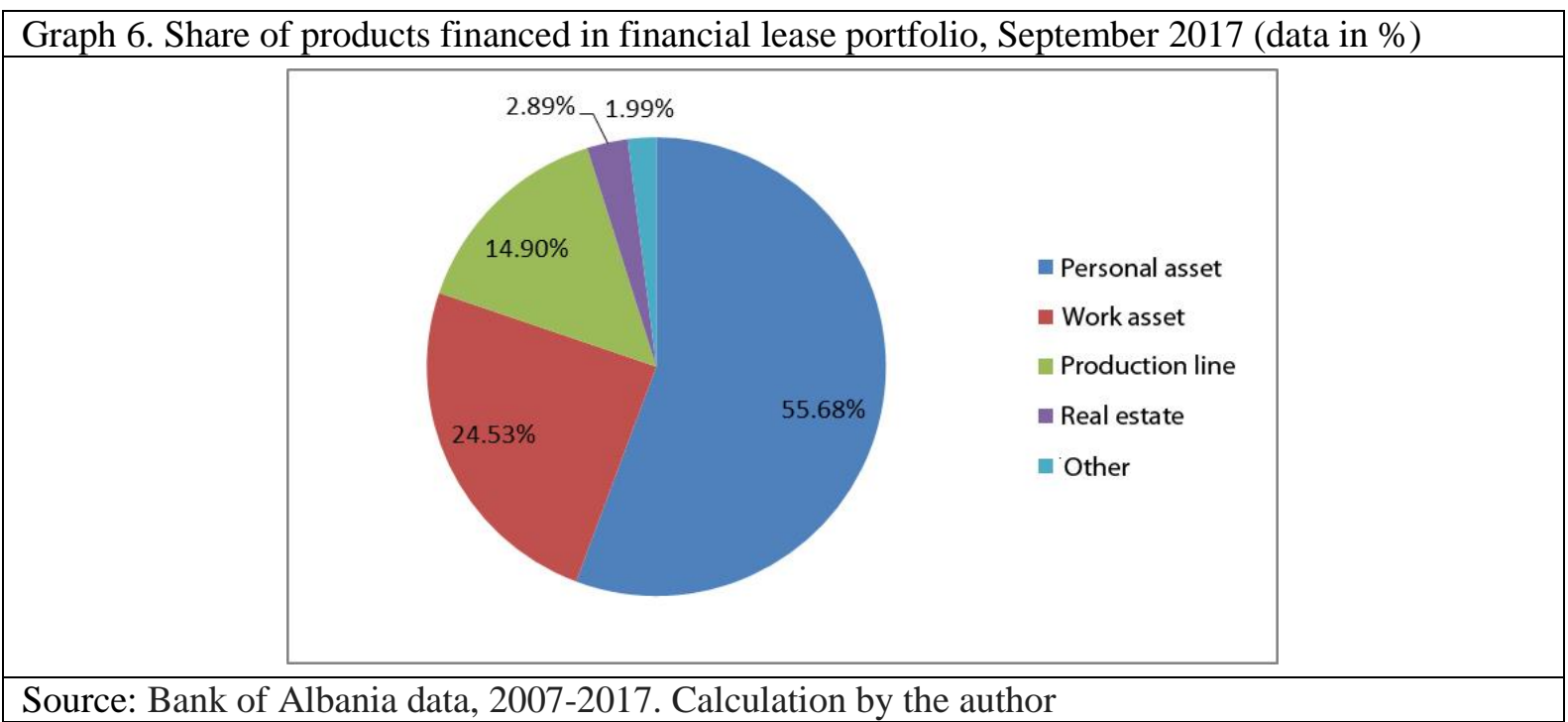

\begin{tabular}{|l|l|l|l|l|l|l|}
\hline Graph 7. Share of used vs. new assets \\
\hline
\end{tabular}

Sectors. During the analyzed period, financial leasing has been consistently focused on financing businesses. This now accounts for over $80 \%$ of the portfolio. The most financed sectors of the economy are "Car and household appliances trade and repair" (14\%), "Real estate, leasing" (12\%) and the "Processing industry" (11\%). It is worth noting that the distribution of financing by sectors has a satisfactory diversification.

Maturity. The financial leasing portfolio during the analyzed period is mainly focused on medium-term financing (1-5 years). Throughout the analyzed period we noticed that the share of medium-term financing has increased from 65\% in 2013 to 85\% in September 2017.

Currency. Currency analysis showed that almost the entire financial leasing portfolio is financed in Euro. This trend reflects the way suppliers provide financing facilities (vehicle and machinery prices are generally paid in Euro). Its effect is reflected in increased exposure of financial leasing entities to risk in two main directions:

1) In the case of foreign currency appreciation, the amount of the payment installment for customers would increase, whose income may be in local currency;

2) VAT receivable ${ }^{4}$ that accumulates in the balance sheet is recorded in the national currency and creates an open foreign exchange position that has not been fully managed by all entities (treated below in supervisory norms).

\footnotetext{
${ }^{4}$ Pursuant to the legislation in force, entities register deductible VAT as being entitled to an asset, as they pay this amount in full at the time of financing lease. The tax law provides that taxes and fees in the Republic of Albania are paid in ALL, thus bringing the forced conversion of this asset and creating a foreign exchange position. On the other hand, entities should collect the VAT paid by customers on each installment (in foreign currency) and pay it
} 


\section{Performance indicators}

The financial result for 2009-2017 is positive for most of the entities. Raiffeisen Leasing is the most profitable and sustainable entity. Credins Leasing and Tirana Leasing, in spite of their positive results, due to the strategies ${ }^{5}$ of the banking groups they were part of, have interrupted their activity. Even the Sogelease entity has achieved a positive and growing financial result over its short 3 year period

Regarding new licensed entities from 2013 till today, it is observed that due to start-up costs they record losses over their first 3 years of operation, and generally start showing positive returns after this period (Albania Leasing, Porsche Leasing, Crimson Finance Fund Albania, Albanian Financial Institution).

Financial results performance of entities as from 2007 (figures in mln ALL)

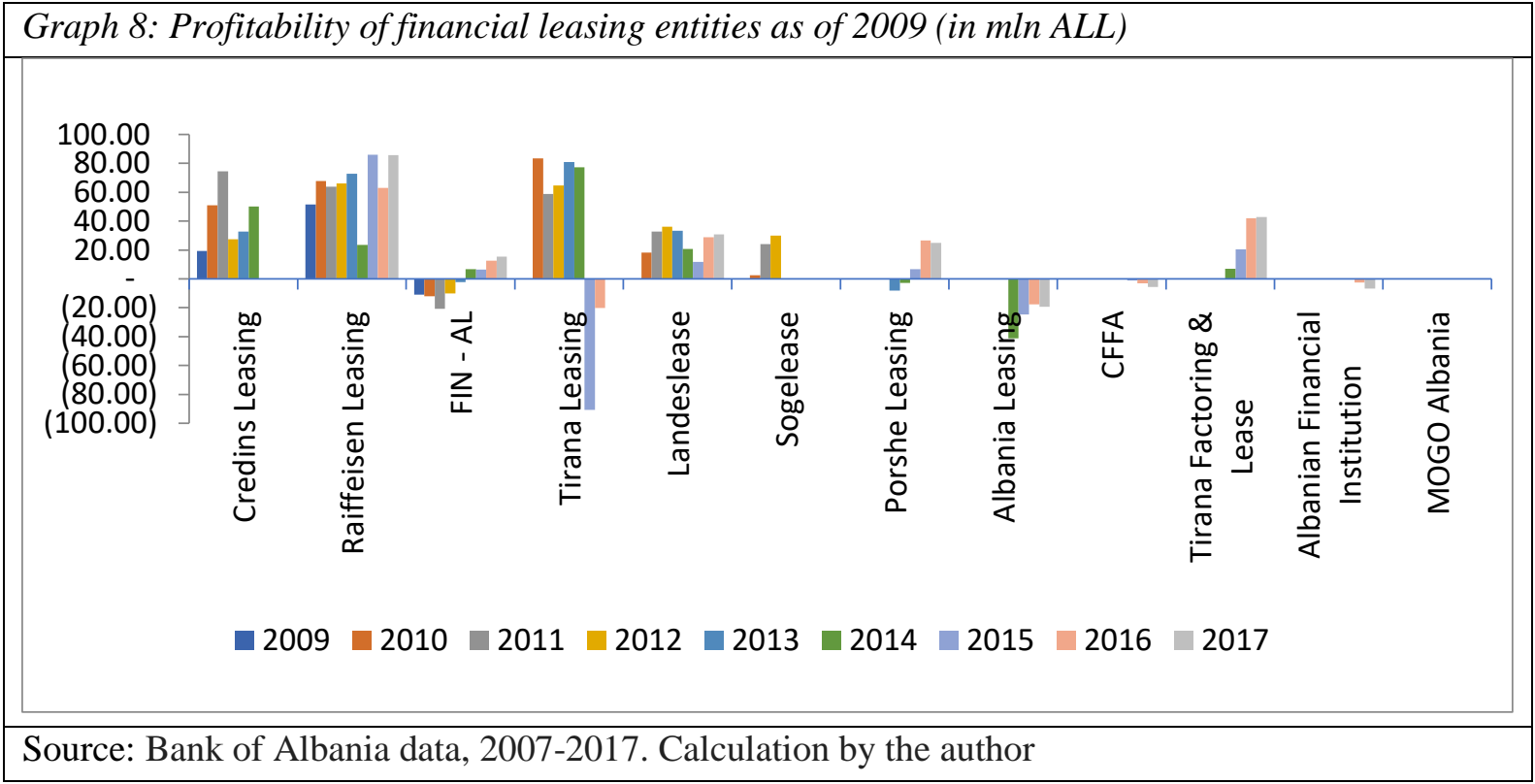

\section{Conclusions}

Financial leasing activity, after a period of stagnation, seems to be regarded as a not fully explored opportunity for financial intermediation. Some of the key factors that are expected to affect the future of the development of financial leasing are as follows:

Strengthening the enforceability of the legal framework and the revival of economic activity is expected to bring a positive impact on the development of financial leasing activity;

The tightening of financing criteria by banks has led to new opportunities for financial leasing entities. An increase in the average amount of financing and an increase in the share of new products (real estate) are some of the signs in this regard;

At a time of increase in capital demand, banks themselves may be interested in transferring certain assets to these entities (e.g. repossessed assets), because capital demands for them are less conservative;

The combination of the above elements, along with the growth of activity, is also expected to bring risks, reflected in non-performing financing. In addition, the combination of their activity with that of banks is expected to increase the complexity of the activity;

Using a high financial leverage (borrowing) may not allow these entities to lower the cost of products, at a time when market interest rates are declining. Moreover, the high leverage also affects (decreases) their ability to cope with risks or decreases in the business cycle, as well as the application of regulatory indicators at all times;

The inability to timely reimburse VAT remains a problem that affects not only the risk of an open foreign exchange position but also the limitation of liquid assets available to entities.

to the tax authorities. The growth of the financing portfolio, as well as long delays in the reimbursement of deductible VAT, have contributed to the expansion of an open foreign exchange position of the entities.

${ }^{5}$ Tirana Leasing has withdrawn from the market due to the withdrawal strategy of the Piraeus group, and Credins Leasing has joined the Credins bank to meet the bank's capital needs. 


\section{References}

Annual monitoring reports 2010-2016, Bank of Albania.

International Accounting Standard 17, Leases (March 2010 version).

International Finance Corporation (IFC). 2009.Leasing in Development: Guidelines for Emerging Economies, Washington, DC

Law no. 7850 "Civil Code of the Republic of Albania", Article 849 "Financial Leasing".

Law no. 9396, dated 12.5.2005 "On financial leasing".

Monitor Journal "Financial leasing, the necessity for secondary market creation", September 2017.

Regulation no. 2, "On supervision of non-banking financial entities activity risk". 